\title{
Construction of $\mathrm{Mn}_{0.5} \mathrm{Mg}_{0.5} \mathrm{Fe}_{2} \mathrm{O}_{4}$ Nano Particles
}

\author{
N. M. Deraz \\ Physical Chemistry Department, Laboratory of Surface Chemistry and Catalysis, \\ National Research Centre, Dokki, Cairo, Egypt
}

\begin{abstract}
M IXED ferrite containing certain amounts of magnesium, manganese and ferric cations was prepared using a simple method. The as prepared ferrite was characterized by X-ray diffraction (XRD), Scanning electron microscopy (SEM) Fourier transform infrared (FTIR) spectroscopy and Energy Dispersive X-ray (EDX) techniques. These techniques revealed that the employed preparation method led to formation of a single phase of nano crystalline $\mathrm{Mn}_{0.5} \mathrm{Mg}_{0.5} \mathrm{Fe}_{2} \mathrm{O}_{4}$ powder which belongs to spinel structure. However, the structural and morphological properties of the as synthesized ferrite were determined. The magnetic properties of the obtained ferrite were investigated using VSM technique. In addition, the results revealed that the surface area of $\mathrm{Mn}_{0.5} \mathrm{Mg}_{0.5} \mathrm{Fe}_{2} \mathrm{O}_{4}$ was greater than that of both $\mathrm{MnFe}_{2} \mathrm{O}_{4}$ and $\mathrm{MgFe}_{2} \mathrm{O}_{4}$.
\end{abstract}

Keywords: XRD; SEM, EDX, Surface area and Mn-Mg ferrite.

\section{Introduction}

Ferrites based on mixed manganese-magnesium constituents have different properties such as high initial permeability coupled with high saturation magnetization and high resistivity good dielectric loss tangents, moderate to broad resonance linewidths, etc. These characteristics brought about various applications of these ferrites such as transformer cores, isolators, circulators, gyrators, phase shifters and switching circuits of digital computers and several other applications $[1,2]$. On other words, importance of nano sized ferrite materials depends upon their chemical and thermal stabilities and ease of their preparation as well as their magnetic, electrical and physical properties [3].

The preparation techniques control not only in the ferrite characteristics like size and shape, but also in their physical properties. Ferrites are commonly prepared by the ceramic technique that involves high-temperature solid state reactions between the constituent oxides yielding particles with large and of non-uniform size $[4,5]$. In this regard De-León-Prado et al report to synthesis of $\mathrm{Mg}_{\mathrm{x}} \mathrm{Mn}_{1-\mathrm{x}} \mathrm{Fe}_{2} \mathrm{O}_{4}(\mathrm{x}=0-1)$ nano particles via sol-gel and thermal decomposition methods [6].

These authors determined the effect of synthesis conditions on the crystal structure and magnetic properties of the ferrites. They obtained ferrites having a single crystalline phase with cubic inverse spinel structure and a behavior near to that of super paramagnetic materials with spherical particle having size of $13 \pm 2 \mathrm{~nm}$. Saturation magnetization values were higher for materials synthesized by sol-gel. However, these materials can be used as thermoseeds for the treatment of cancer by magnetic hyperthermia. Several methods resulted in production of ferrites, among these methods the combustion route which is promising technique to synthesis at low temperatures due to its simplicity and interesting advantages [7].

Due to the technological importance of $\mathrm{Mn}-\mathrm{Mg}$ ferrites, this study aims to prepare $\mathrm{Mn}-\mathrm{Mg}$ ferrite using glycine-assisted combustion technique. Another goal for this research is the study of the structural, magnetic and morphological properties of the as prepared $\mathrm{Mn}$ - Mg ferrite. The techniques employed were XRD, IR, SEM, EDX and VSM.

\section{Experimental}

\section{Materials}

Mixing calculated amounts of manganese, magnesium and iron nitrates with a certain amount of glycine as fuel resulted in preparation of $\mathrm{Mn}_{0.5} \mathrm{Mg}_{0.5} \mathrm{Fe}_{2} \mathrm{O}_{4}$ nano particles as reported by Deraz [8]. In a pyrex beaker, intensive mixed

Corresponding author. Tel.: +20 121 625401; fax: +20 233370913 .

E-mail address: nmderaz@yahoo.com

DOI: 10.21608/EJCHEM.2018.3112.1262

C2017 National Information and Documentation Centre (NIDOC) 
precursors heated at $80{ }^{\circ} \mathrm{C}$ to obtain gel then the materials heated at $350{ }^{\circ} \mathrm{C}$ for 5 minutes to evaporate the water crystal. Herein, spark appeared, and a good deal of foams produced at one corner giving a brown superfine massive product. In the order already mentioned ratio of the $\mathrm{H}_{2} \mathrm{NCH}_{2} \mathrm{COOH}: \mathrm{Mn}\left(\mathrm{NO}_{3}\right)_{2} \cdot 4 \mathrm{H}_{2} \mathrm{O}$ : $\mathrm{Mg}\left(\mathrm{NO}_{3}\right)_{2} \cdot 6 \mathrm{H}_{2} \mathrm{O}: \mathrm{Fe}\left(\mathrm{NO}_{3}\right)_{3} \cdot 9 \mathrm{H}_{2} \mathrm{O}$ were $4: 0.5$ : $0.5: 2$, respectively. The chemicals employed from where analytical grade supplied by Prolabo Company. Process flowchart for fabricating the as prepared sample illustrated in Fig. 1.

\section{Techniques}

An X-ray measurement of various mixed solids was carried out using a BRUKER D8 advance diffractometer (Germany). The patterns were run with $\mathrm{Cu} \mathrm{K}$ radiation at $40 \mathrm{kV}$ and 40 $\mathrm{mA}$ with scanning speed in $2 \theta$ of $2^{\circ} \mathrm{min}^{-1}$.

The crystallite size of $\mathrm{Mn}_{0.5} \mathrm{Mg}_{0.5} \mathrm{Fe}_{2} \mathrm{O}_{4}$ present in the investigated solids was based on X-ray diffraction line broadening and calculated by using Scherrer equation [9].

$$
d=\frac{B \lambda}{\beta \cos \theta}
$$

where $d$ is the average crystallite size of the phase under investigation, $\mathrm{B}$ is the Scherrer constant (0.89), $\lambda$ is the wave length of X-ray beam used, $\beta$ is the full-with half maximum (FWHM) of diffraction and $\theta$ is the Bragg's angle. $200 \mathrm{mg}$ of vacuum-dried IR grade material that is usually used in IR measurements is potassium bromide ( $\mathrm{KBr}$ ) mixed with $2 \mathrm{mg}$ of examined solid sample, the mixture dispersed in a gate mortar, placed in a steel die, subjected to 5 ton pressure to get disks samples which placed in the holder of the double grating Perkin-Elmer IR Spectrophotometer. IR Spectrum recorded from 4000 to $400 \mathrm{~cm}^{-1}$.

Scanning electron microscopy (SEM) was recorded on SEM-JEOL JAX-840A electron microanalyzer (Japan). The samples were dispersed in ethanol and then treated ultrasonically in order disperse individual particles over a gold grids.

Energy dispersive X-ray (EDX) analysis was carried out on Hitachi S-800 electron microscope with an attached kevex Delta system. The parameters were as follows: accelerating voltage $20 \mathrm{kV}$, accumulation time $100 \mathrm{~s}$, window width $8 \mu \mathrm{m}$. The surface molar composition was determined by the Asa method, Zaf-correction, Gaussian approximation.

Vibrating sample magnetometer (VSM; 96001 LDJ, USA) used to investigate the magnetic properties of the investigated solids in a maximum applied field of $15 \mathrm{kOe}$. Hysteresis loops, saturation magnetization $\left(\mathrm{M}_{\mathrm{s}}\right)$, remanence magnetization $\left(\mathrm{M}_{\mathrm{r}}\right)$ and coercivity $\left(\mathrm{H}_{\mathrm{c}}\right)$ determined.

\section{Results}

Evidence formation of a single phase of $\mathrm{Mn}_{0.5} \mathrm{Mg}_{0.5} \mathrm{Fe}_{2} \mathrm{O}_{4}$ nanoparticles

XRD investigation was evidenced formation a single phase of $\mathrm{Mn}_{0.5} \mathrm{Mg}_{0.5} \mathrm{Fe}_{2} \mathrm{O}_{4}$ nano particles as shown in Fig. 2. It found that $\mathrm{Mn}_{0.5} \mathrm{Mg}_{0.5} \mathrm{Fe}_{2} \mathrm{O}_{4}$ solid have cubic spinel structure with the $\mathrm{Fd} 3 \mathrm{~m}$ space group (JCPDS card No. 80-0072). The peaks of the as synthesized solid were indexed to the crystal plane of spinel Mn- Mg ferrite ( $\left.\begin{array}{lll}1 & 1 & 1\end{array}\right)$, (2 2 0), (311), (2 2 2), (4 0 0), (4 2 2 2), (5 11 1), (4 4 0), (6 20 0), (5 33 3), (6 22 2), (4 44 4) and (6 4 2), respectively. Inspection of the XRD pattern of the solid studied displays absence of any additional peak related to any second phase indicating complete conversion of the reacting constituents to the corresponding ferrite. Thus, addition of

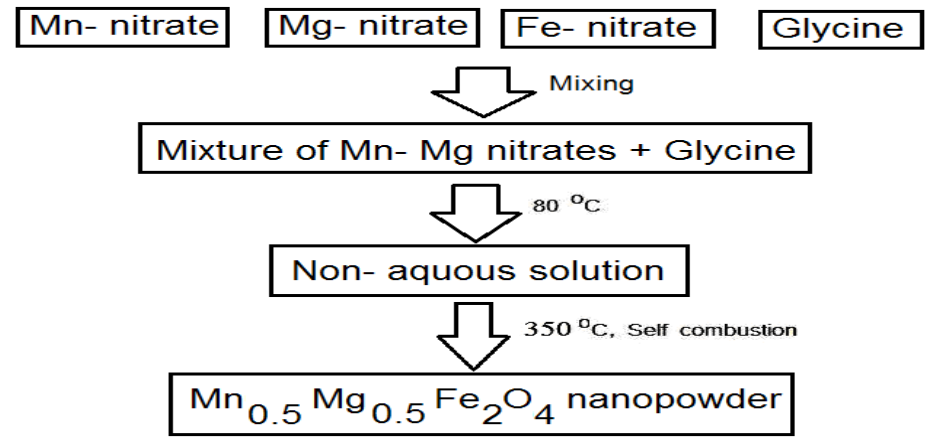

Fig. 1. Process flowchart for fabricating the as prepared sample. 


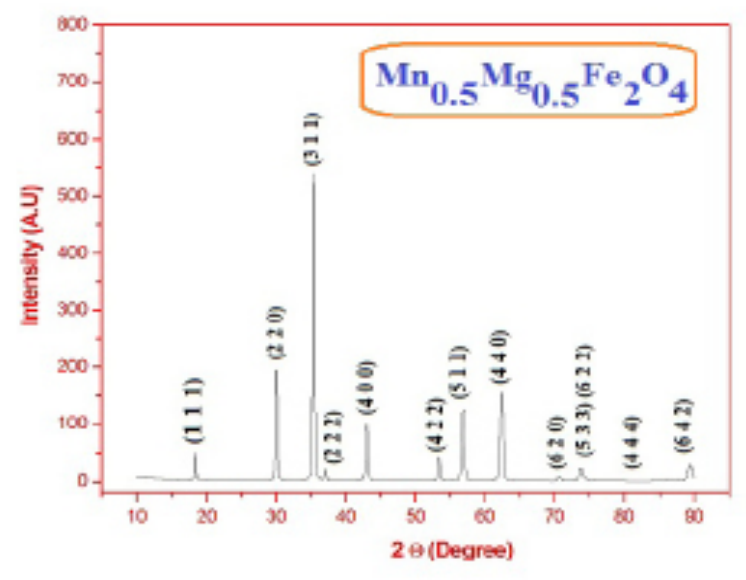

Fig. 2. XRD pattern for the as prepared Mn-Mg ferrite.

small amount of glycine to $\mathrm{Mn}-\mathrm{Mg}$ - Fe nitrates followed by heating at $350{ }^{\circ} \mathrm{C}$ for $5 \mathrm{~min}$. led to stimulating the solid state between the reacting oxides yielding $\mathrm{Mn}_{0.5} \mathrm{Mg}_{0.5} \mathrm{Fe}_{2} \mathrm{O}_{4}$ crystallites.

On the other hand, the X-ray data enabled us to calculate the different structural parameters of cubic spinel Mn- Mg ferrite such as the crystallite size (d), lattice constant (a), unit cell volume (V), X-ray density $\left(\mathrm{D}_{\mathrm{x}}\right)$, the distance between the reacting ions $\left(\mathrm{L}_{\mathrm{A}}\right.$ and $\left.\mathrm{L}_{\mathrm{B}}\right)$, ionic radii $\left(\mathrm{r}_{\mathrm{A}}, \mathrm{r}_{\mathrm{B}}\right)$ and bond lengths $(\mathrm{A}-\mathrm{O}$ and $\mathrm{B}-\mathrm{O})$ on tetrahedral (A) sites and octahedral (B) sites, however, the specific surface area (S). The values of various structural parameters and surface area of $\mathrm{Mn}-\mathrm{Mg}$ ferrite were tabulated in Tables 1 and 2.

\section{IR analysis}

In fact, the spinel ferrites display two main metal- oxygen bands in IR pattern [10]. One of these bands related to tetrahedral (A) site while the second band refers to octahedral (B) site, these sites construct the spinel structure and located at 600 $\mathrm{cm}^{-1}$ and $400 \mathrm{~cm}^{-1}$, according to the geometrical configuration of materials. . In our experiment, IR spectra of the as prepared ferrite were ranged from 4000 to $400 \mathrm{~cm}^{-1}$ as shown in Fig. 3. In this study, IR pattern shows two bands located at 1635 and 3465 $\mathrm{cm}^{-1}$ related to the stretching modes and $\mathrm{H}-\mathrm{O}-\mathrm{H}$ bending vibration of the free or absorbed water [11]. In addition, This pattern involved highest band locates $559 \mathrm{~cm}^{-1}$, corresponds to intrinsic stretching vibrations of metal at the tetrahedral site, and also lowest band, appears at $425 \mathrm{~cm}^{-1}$, assigned to octahedral- metal stretching.

\section{The morphology study}

The SEM morphology of the synthesized sample was determined in Fig. 4. This figure shows spongy, fluffy, foamy and fragile material containing voids and pores. These voids and pores could be attributed to release of large amounts of gases during combustion process depending on the decomposition of both glycine and metals nitrates.

\section{Homogeneity of the as prepared samples}

Various points on surface of the $\mathrm{Mn}_{0.5} \mathrm{Mg}_{05} \mathrm{Fe}_{2} \mathrm{O}_{4}$ solid are investigated by using energy dispersive $\mathrm{X}$-ray (EDX) analysis at 20 $\mathrm{keV}$ as shown in Fig. 5. This figure revealed that the as synthesized solid consisted entirely of $\mathrm{O}$, $\mathrm{Mg}, \mathrm{Mn}$ and $\mathrm{Fe}$ elements. However, the relative atomic abundance of $\mathrm{O}, \mathrm{Mg}, \mathrm{Mn}$ and $\mathrm{Fe}$ species, present in the surface layers of the as prepared sample at three different points, as example, are tabulated in Table 3. It can be seen from this table that the surface concentrations of $\mathrm{O}, \mathrm{Mg}, \mathrm{Mn}$ and $\mathrm{Fe}$ species on different points over the surface of specimens studied are much closed to each other. This indicates the homogeneous distribution of these species in the sample studied. Thus, the combustion route resulted in production of homogeneously distributed materials.

\section{The magnetic properties}

The magnetic properties of the as-prepared powders were determined by measuring the magnetic hysteresis loop at room temperature as shown in Fig. 6. The values of $\mathrm{M}_{\mathrm{s}}, \mathrm{M}_{\mathrm{r}}$ and $\mathrm{H}_{\mathrm{c}}$ for the as prepared composite were $47.78^{\mathrm{r}} \mathrm{emu} / \mathrm{g}$, $13.81 \mathrm{emu} / \mathrm{g}$ and $97.36 \mathrm{Oe}$, respectively. The comparison between these values and that for both $\mathrm{MnFe}_{2} \mathrm{O}_{4}$ and $\mathrm{MgFe}_{2} \mathrm{O}_{4}$ which investigated in our previous works was showed that the magnetic parameters of the as prepared composite are ranged between that for both $\mathrm{Mn}$ - ferrite $(67.18$ $\mathrm{emu} / \mathrm{g})$ and $\mathrm{Mg}$ - ferrite $(27.92 \mathrm{emu} / \mathrm{g})[10,12]$.

\section{Surface area of the as prepared sample}

The surface area of the as synthesized sample 
TABLE 1. The values of $d, a, V, D_{x}$ and $S$ of the as prepared $\mathrm{Mn}_{0.5} \mathrm{Mg}_{0.5} \mathrm{Fe}_{2} \mathrm{O}_{4}$ solid.

\begin{tabular}{|c|c|c|c|c|c|}
\hline Sample & $\begin{array}{c}\mathrm{d} \\
(\mathrm{nm})\end{array}$ & $\begin{array}{c}\mathrm{a} \\
(\mathrm{nm})\end{array}$ & $\begin{array}{c}\mathrm{V} \\
\left(\mathrm{nm}^{3}\right)\end{array}$ & $\begin{array}{c}\mathrm{D}_{\mathrm{x}} \\
\left(\mathrm{g} / \mathrm{cm}^{3}\right)\end{array}$ & $\begin{array}{c}\mathrm{S} \\
\left(\mathrm{m}^{2} / \mathrm{g}\right)\end{array}$ \\
\hline $\mathrm{Mn}_{0.5} \mathrm{Mg}_{0.5} \mathrm{Fe}_{2} \mathrm{O}_{4}$ & 30 & 0.8350 & 0.5321 & 5.3619 & 37.30 \\
\hline
\end{tabular}

TABLE 2. The values of $L_{A}, L_{B}, A-O, B-O, r_{A}$ and $r_{B}$ for the as prepared $M_{0.5} M_{0.5} F_{2} O_{4}$ solid.

\begin{tabular}{|c|c|c|c|c|c|c|} 
Sample & $\begin{array}{c}\mathbf{L}_{\mathrm{A}} \\
(\mathrm{nm})\end{array}$ & $\begin{array}{c}\mathbf{L}_{\mathrm{B}} \\
(\mathrm{nm})\end{array}$ & $\begin{array}{c}\mathrm{A}-\mathrm{O} \\
(\mathrm{nm})\end{array}$ & $\begin{array}{c}\mathrm{B}-\mathrm{O} \\
(\mathrm{nm})\end{array}$ & $\begin{array}{c}\mathbf{r}_{\mathrm{A}} \\
(\mathrm{nm})\end{array}$ & $\begin{array}{c}\mathbf{r}_{\mathrm{B}} \\
(\mathbf{n m})\end{array}$ \\
$\mathrm{Mn}_{0.5} \mathrm{Mg}_{0.5} \mathrm{Fe}_{2} \mathrm{O}_{4}$ & $\mathbf{0 . 3 3 9 0}$ & $\mathbf{0 . 2 7 4 5}$ & $\mathbf{0 . 1 7 1 0}$ & $\mathbf{0 . 1 8 7 0}$ & $\mathbf{0 . 0 4 5 7}$ & $\mathbf{0 . 0 6 2 0}$ \\
\hline
\end{tabular}

TABLE 3. The atomic abundance of elements measured at $20 \mathrm{KeV}$ and different points over the as- prepared sample.

Atomic abundance (\%)

\begin{tabular}{cccc} 
Elements & Point (1) & Point (2) & Point (3) \\
\hline $\mathrm{O}$ & 23.27 & 23.22 & 23.06 \\
$\mathrm{Mg}$ & 09.35 & 08.90 & 07.29 \\
$\mathrm{Mn}$ & 16.96 & 15.95 & 18.18 \\
$\mathrm{Fe}$ & 73.65 & 75.14 & 74.53 \\
\hline
\end{tabular}

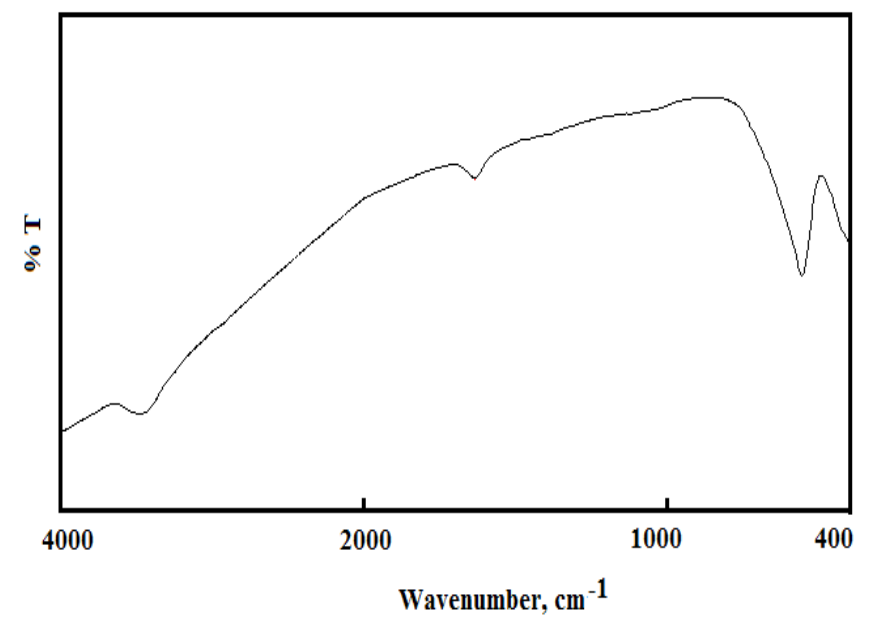

Fig. 3. IR for the as prepared Mn-Mg ferrite. 


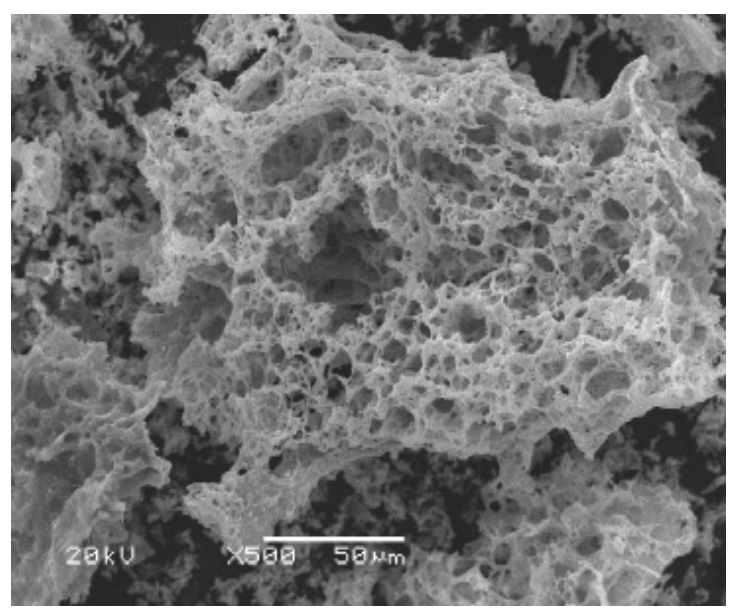

Fig. 4. SEM for the as prepared Mn-Mg ferrite.

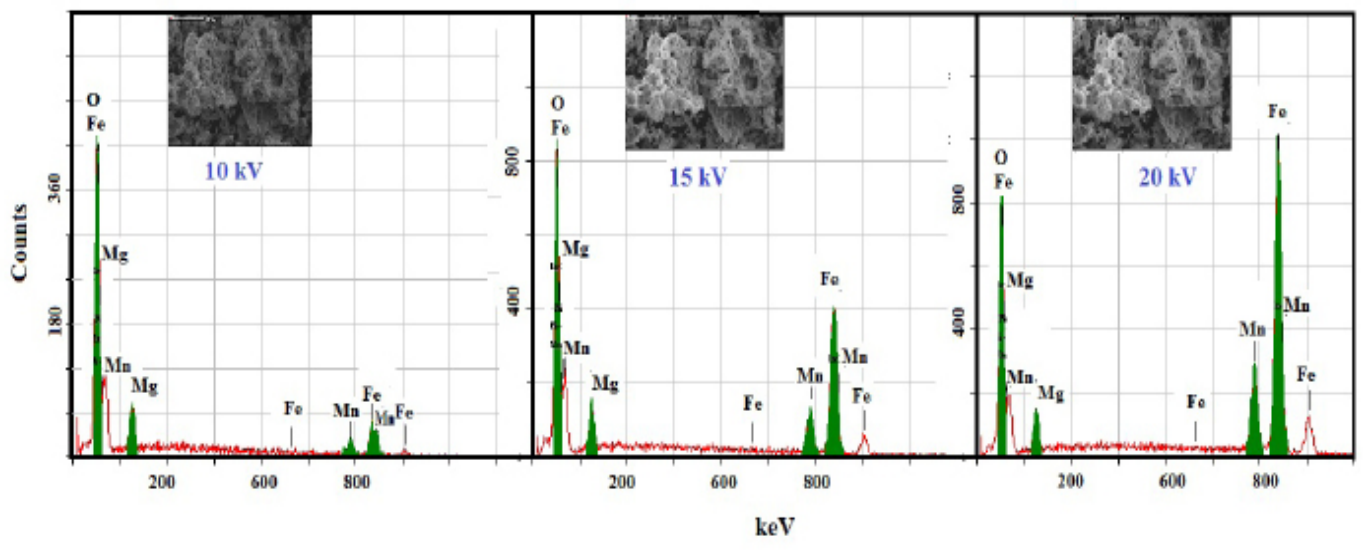

Fig. 5. EDX pattern for the as prepared Mn-Mg ferrite.

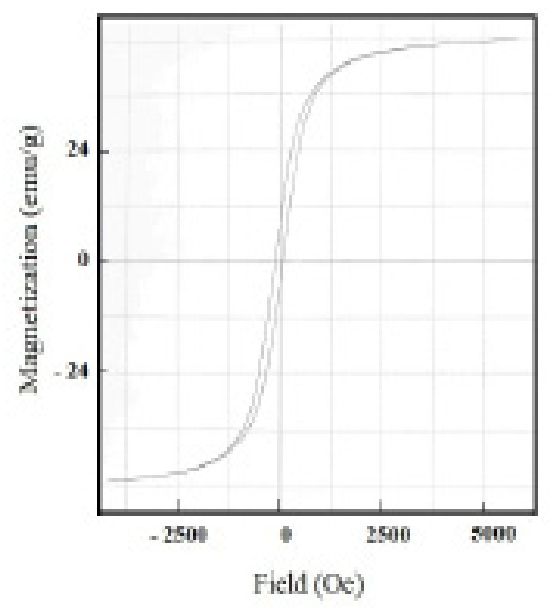

Fig. 6. Magnetic hysteresis curves measured at a room temperature for the as prepared Mn-Mg ferrite. 
is $37.3 \mathrm{~m}^{2} / \mathrm{g}$ while that of simple ferrites are 22.4 and $35.1 \mathrm{~m}^{2} / \mathrm{g}$ for magnesium and manganese ferrites, respectively. This shows that the promotion effect of both $\mathrm{Mg}$ and $\mathrm{Mn}$ in case of $\mathrm{Mn}_{0.5} \mathrm{Mg}_{0.5} \mathrm{Fe}_{2} \mathrm{O}_{4}$. In other words, the presence of $\mathrm{Mn}$ and $\mathrm{Mg}$ together led to an increase in the surface area of the fabricated sample compared with that of both $\mathrm{MnFe}_{2} \mathrm{O}_{4}$ and $\mathrm{MgFe}_{2} \mathrm{O}_{4}$.

\section{Discussion}

Glycine assisted - combustion route is promising technique to synthesis of $\mathrm{Mn}_{0.5} \mathrm{Mg}_{0.5} \mathrm{Fe}_{2} \mathrm{O}_{4}$ nanopowder. In our previous works, this method was suitable for preparation different ceramic materials especially various simple ferrite such as $\mathrm{MnFe}_{2} \mathrm{O}_{4}$, $\mathrm{MgFe}_{2} \mathrm{O}_{4}$ and so on [10, 12]. Generally, the solid state between the reacting constituents to form the corresponding ferrite resulted in rigid ferrite film surrounding the reacting oxides [12]. The diffusion of $\mathrm{Mg}^{+2}, \mathrm{Mn}^{+2}$ and $\mathrm{Fe}^{+3}$ through early rigid ferrite film led to an increase in the formation of $\mathrm{Mn}_{0.5} \mathrm{Mg}_{0.5} \mathrm{Fe}_{2} \mathrm{O}_{4}$ particles depending upon the similarity of the ionic radii of ferric, manganese and magnesium species $[10,12]$. The mechanism of formation $\mathrm{Mn}_{05} \mathrm{Mg}_{05} \mathrm{Fe}_{2} \mathrm{O}_{4}$ can be simplified as following [7]: At $\mathrm{Fe}_{2} \mathrm{O}_{3}$ interface:

$3 \mathrm{Fe}_{2} \mathrm{O}_{3}+\mathrm{Mn}^{+2}+\mathrm{Mg}^{+2} \rightarrow 2 \mathrm{Mn}_{0.5} \mathrm{Mg}_{0.5} \mathrm{Fe}_{2} \mathrm{O}_{4}+$ $2 \mathrm{Fe}^{+2}+0.5 \mathrm{O}_{2}$

At $\mathrm{MnO}$ and $\mathrm{MgO}$ interfaces:

$2 \mathrm{Fe}^{+2}+1.5 \mathrm{MnO}+1.5 \mathrm{MgO}+0.5 \mathrm{O} 2 \rightarrow$ $\mathrm{Mn}_{0.5} \mathrm{Mg}_{0.5} \mathrm{Fe}_{2} \mathrm{O}_{4}+\mathrm{Mn}^{+2}+\mathrm{Mg}^{+2}$

In fact, the values of structural parameters such as the lattice constant and the unit cell volume for $\mathrm{Mn}_{0.5} \mathrm{Mg}_{0.5} \mathrm{Fe}_{2} \mathrm{O}_{4}$ system in this study are ranged between that for both $\mathrm{MnFe}_{2} \mathrm{O}_{4}$ and $\mathrm{MgFe}_{2} \mathrm{O}_{4}$ solids determined in our previous researches [ $[10$, 12]. These findings confirm formation of solid solution between $\mathrm{MnFe}_{2} \mathrm{O}_{4}$ and $\mathrm{MgFe}_{2} \mathrm{O}_{4}$ yielding $\mathrm{Mn}_{0.5} \mathrm{Mg}_{0.5} \mathrm{Fe}_{2} \mathrm{O}_{4}$. Table 1 shows that the crystallite sizes of $\mathrm{MnFe}_{2} \mathrm{O}_{4}$ and $\mathrm{MgFe}_{2} \mathrm{O}_{4}$ are greater that of $\mathrm{Mn}_{0.5} \mathrm{Mg}_{0.5} \mathrm{Fe}_{2} \mathrm{O}_{4}$ based on the difference in the ionic radii of the $\mathrm{Mn}, \mathrm{Mg}$ and $\mathrm{Fe}$ cations. This behavior was observed in the calculated lattice constant of these ferrites. The replacement of $\mathrm{Mn}^{2+}(0.08 \mathrm{~nm})$ or/and $\mathrm{Mn}^{3+}$ by $\mathrm{Mg}^{2+}(0.065 \mathrm{~nm})$ brought about a decrease in the lattice constant of $\mathrm{Mn}_{0.5} \mathrm{Mg}_{0.5} \mathrm{Fe}_{2} \mathrm{O}_{4}$ with subsequent decrease in the crystallite size. This indicates the contraction in the crystal lattice of prepared mixed ferrite. This interpreted the highest difference between the crystallite size of $\mathrm{MgFe}_{2} \mathrm{O}_{4}$ and that of $\mathrm{MnFe}_{2} \mathrm{O}_{4}$. Thus, the author can be suggested that the replacement of $\mathrm{Mn}$ by $\mathrm{Mg}$ during the ferrite preparation yielding $\mathrm{Mn}_{0.5} \mathrm{Mg}_{0.5} \mathrm{Fe}_{2} \mathrm{O}_{4}$ resulted in an improvement in related structural properties such as the distance between the reacting ions $\left(\mathrm{L}_{\mathrm{A}}\right.$ and $\left.\mathrm{L}_{\mathrm{B}}\right)$, ionic radii $\left(\mathrm{r}_{\mathrm{A}}, \mathrm{r}_{\mathrm{B}}\right)$ and bond lengths $(\mathrm{A}-\mathrm{O}$ and $\mathrm{B}-\mathrm{O})$ on tetrahedral (A) sites and octahedral (B) sites.

Egypt. J. Chem. 61, No. 3 (2018)
The exact and careful examination of Table 1 indicates that the surface area of the prepared mixed sample is rather large compared to the nonmixed samples. This table shows that the surface area of $\mathrm{MnFe}_{2} \mathrm{O}_{4}, \mathrm{MgFe}_{2} \mathrm{O}_{4}$ and $\mathrm{Mn}_{0.5} \mathrm{Mg}_{0.5} \mathrm{Fe}_{2} \mathrm{O}_{4}$ are $35.1,22.4$ and $37.3 \mathrm{~m}^{2} / \mathrm{g}$, respectively. This could be attributed to the decrease in the particle size of $\mathrm{Mn}_{05} \mathrm{Mg}_{0.5} \mathrm{Fe}_{2} \mathrm{O}_{4}$ yielding more nano powders. In addition, the increase in the voids and pores involved in the as prepared $\mathrm{Mn}_{0.5} \mathrm{Mg}_{0.5} \mathrm{Fe}_{2} \mathrm{O}_{4}$ due to release of large amounts of gases during the decomposition of both glycine and metals nitrates. However, IR study confirms the formation of spinel $\mathrm{Mn}_{0.5} \mathrm{Mg}_{0.5} \mathrm{Fe}_{2} \mathrm{O}_{4}$ based nano structured material. EDX measurements showed that the surface concentrations of $\mathrm{Mn}$, $\mathrm{Mg}, \mathrm{O}$ and $\mathrm{Fe}$ species for the as prepared sample at different points are very close to each other. SEM and EDX investigations showed that the investigated method led to formation of spongy and homogeneous solid.

Indeed, the values of $M_{s}, M_{r}, H_{c}$ for $\mathrm{Mn}_{0.5} \mathrm{Mg}_{0.5} \mathrm{Fe}_{2} \mathrm{O}_{4}$ system in this study are ranged between that for both $\mathrm{MnFe}_{2} \mathrm{O}_{4}$ and $\mathrm{MgFe}_{2} \mathrm{O}_{4}$ solids determined in our previous researches [10, 12]. This attributed to redistribution of $\mathrm{Mn}, \mathrm{Mg}$ and $\mathrm{Fe}$ species between the octahedral and tetrahedral sites involved in the investigated spinel structure. These findings depend upon the relation between the magnetic parameters, particularly magnetization and coercivity of the different ferrites and both of the inversion degree of distribution of cationic ions between the tetrahedral (A) and octahedral sites (B) of the spinel lattice and the spin disorder in the shell around the core [10, 12-14]. However, the inversion degree of distribution of cationic ions and the spin order depend upon the particle size and lattice parameters. On the other hand, the spin orders depend on the surface effects. These surface effects dominate the magnetic properties of nano particles because the decrease in the particle size brought about an increase in the ratio of surface spins to the total number of spins. Thus, the magnetic behavior of the particle surface differs from that corresponding to the core due to the distinct atomic coordination, compositional gradients, concentration and nature of the defects. In additional, the core usually displays a spin canting and arrangement similar to that of the bulk material.

In this study, the coercivity of $\mathrm{Mn}_{0.5} \mathrm{Mg}_{0.5} \mathrm{Fe}_{2} \mathrm{O}_{4}$ is greater than that of $\mathrm{MnFe}_{2} \mathrm{O}_{4}$ and $\mathrm{MgFe}_{2} \mathrm{O}_{4}$ solids prepared in our previous work using the combustion method with the same conditions. This is due to the decrease in the particle size of the as prepared solid according to Kittel's theory $[15,16-$ $20]$. The values of Bohr magneton $\left(\mu_{\mathrm{B}}\right)$ are 0.9999 , 1.8414 and 2.7740 for $\mathrm{MgFe}_{2} \mathrm{O}_{4}, \mathrm{Mn}_{0.5} \mathrm{Mg}_{0.5} \mathrm{Fe}_{2} \mathrm{O}_{4}$ 
and $\mathrm{MnFe}_{2} \mathrm{O}_{4}$, respectively. This indicates that the replacement of $\mathrm{Mg}$ by $\mathrm{Mn}$ species led to an increase in the value of $\mu_{\mathrm{B}}$ relative to that of $\mathrm{MgFe}_{2} \mathrm{O}_{4}$ as shown in the case of $\mathrm{Mn}_{0.5} \mathrm{Mg}_{0.5} \mathrm{Fe}_{2} \mathrm{O}_{4}$, vice versa. The same behavior was observed in the values of $M_{r}, M_{s}$ and $M_{r} / M_{s}[21-22]$.

\section{Conclusions}

Glycine- assisted combustion method resulted in formation of $\mathrm{Mn}_{0.5} \mathrm{Mg}_{0.5} \mathrm{Fe}_{2} \mathrm{O}_{4}$ via the solid state reaction between $\mathrm{Mn}-\mathrm{Mg}$ - Fe oxides. XRD and IR confirm the formation of $\mathrm{Mn}_{0.5} \mathrm{Mg}_{0.5} \mathrm{Fe}_{2} \mathrm{O}_{4}$ as single spinel phase. XRD data enabled us to calculate the lattice constant, unit cell volume, $\mathrm{X}$-ray density, specific surface area, the distance between the magnetic ions, ionic radii and bond lengths on tetrahedral sites and octahedral sites of $\mathrm{Mn}_{0.5} \mathrm{Mg}_{0.5} \mathrm{Fe}_{2} \mathrm{O}_{4}$ crystallites. SEM technique shows formation of spongy, fragile and homogenous material. The element analysis of the as prepared sample determined using EDX technique. The values of $\mathrm{M}_{\mathrm{s}}, \mathrm{M}_{\mathrm{r}}$ and $\mathrm{H}_{\mathrm{c}}$ for the as prepared composite were $47.78 \mathrm{emu} / \mathrm{g}, 13.81$ emu/g and $97.36 \mathrm{Oe}$, respectively.

\section{References}

1. Papian W.N. , Proc. Metal Powder Assoc., Vol. 2, London (Great Britain) 183 (1955).

2. Carl Heck, Magnetic Materials and their Applications, Butter worths, London, (1974).

3. Singh M. and Sud S.P., Controlling the properties of magnesium-manganese ferrites. Mater. Sci. Eng., B 83, 180-184 (2001).

4. Deraz N. M., Production and characterization of pure and doped copper ferrite nanoparticles. $J$. Anal. Appl. Pyrol. , 82(2), 212-222 (2008).

5. Modi K. B., Vasoya N. H., Lakhani V. K. and Pathak T. K., Magnetic phase evolution and particle size estimation study on nanocrystalline Mg-Mn ferrites. Appl. Nanosci., 5, 11-17 (2015).

6. De-León-Prado L. E., Cortés-Hernández D. A., Almanza-Robles J. M., Escobedo-Bocardo J. C., Sánchez J., Reyes-Rdz, P. Y., Jasso-Terán R. A. and Hurtado-López G. F., Synthesis and characterization of nanosized $\mathrm{Mg}_{\mathrm{x}} \mathrm{Mn}_{1-\mathrm{x}} \mathrm{Fe}_{2} \mathrm{O}_{4}$ ferrites by both solgel and thermal decomposition methods, J. Magn. Magn. Mater., 427, 230-247 (2017).

7. Deraz N. M. and Abd-Elkader Omar H., Structural, Morphological and Magnetic Properties of $\mathrm{Zn}_{0.5} \mathrm{Mg}_{0.5} \mathrm{Fe}_{2} \mathrm{O}_{4}$ as Anticorrosion Pigment. Int. J. Electrochem. Sci., 10, 7138 - 7146 (2015).

8. Deraz N. M. Glycine-assisted fabrication of nanocrystalline cobalt ferrite system. J. Anal. Appl. Pyrol., 88, 103-109 (2010).
9. B.D. Cullity: "Elements of X-ray Diffraction" Chap. 14, Addison-Wesly Publishing Co. Inc. (1976).

10. Deraz N. M. and Alarifi A. Novel preparation and properties of magnesioferrite nanoparticles. $J$. Anal. Appl. Pyrol. 97, 55-61 (2012).

11. Sankaranarayanan and V.K., Sreekumar C., Precursor synthesis and microwave processing of nickel ferrite nanoparticles. Curr. Appl. Phys. 3, 205- 208 (2003).

12. Deraz N. M. and Shaban S., Optimization of catalytic, surface and magnetic properties of nanocrystalline manganese ferrite. J. Anal. Appl. Pyrol. 86, 173-179 (2009).

13. Chen J.P., Sorensen C.M., Klabunde K.J., Hadjipanayis G.C., Devlin E. and Kostikas A., Sizedependent magnetic properties of $\mathrm{MnFe}_{2} \mathrm{O}_{4}$ fine particles synthesized by coprecipitation. Phys. Rev. B 54, 9288-9296 (1996).

14. J.H. Liu, L. Wang, F.S. Li, Magnetic properties and Mössbauer studies of nanosized $\mathrm{NiFe}_{2} \mathrm{O}_{4}$ particles, J. Mater. Sci. 40, 2573-2575 (2005).

15. Kittel C., Theory of the Dispersion of Magnetic Permeability in Ferromagnetic Materials at Microwave Frequencies, Phys. Rev., 70(11-12), 965-971(1946).

16. Kittel C., On the Theory of Ferromagnetic Resonance Absorption. Phys. Rev., 73(2), 155-161(1948).

17. Takeshi Nomura, in: Magnetic Ceramics, Handbook of Advanced Ceramics, Elsevier, (2003).

18. Clegg A.G., Beckley P., Snelling E.C. and Major R.V., in: Magnetic Materials, Electrical Engineer's Reference Book, Sixteenth Edition, Elsevier, (2003).

19. Pardavi-Horvath M., Microwave applications of soft ferrites. J. Magn. Magn. Mater. 215-216, 171-183 (2000).

20. Gopalan E.V., Malini K.A., Saravanan S., Kumar D.S., Yoshida Y. and Anantharaman M.R., Evidence for polargon conduction in nanostructured managese ferrite. J. Phys. D: Appl. Phys. 41, 185005 (2008).

21. Kenyota1 N. and Sitthisart S., The investigation of physical and electrical properties of $\mathrm{Mn}_{1}$. $\mathrm{MgxFe}_{2} \mathrm{O}_{4}$ ceramics, IOP Conf. Series: Journal of Physics: Conf. Series 901, 012087 (2017).

22. Zhou K., Wu W., LiY. , Wu X., Liao S., Preparation of magnetic nanocrystalline $\mathrm{Mn}_{0.5} \mathrm{Mg}_{0.5} \mathrm{Fe}_{2} \mathrm{O}_{4}$ and kinetics of thermal decomposition of precursor, $J$. Therm. Anal. Calorim., 114 (1), 205 (2013).

(Received 15/3/2018; accepted 12/4/2018)

Egypt. J. Chem. 61, No. 3 (2018) 


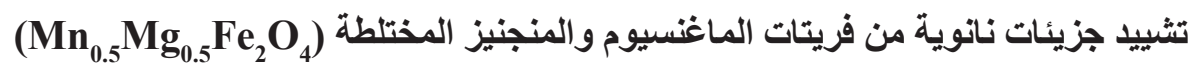

نصر الله محمد محمود دراز

معمل كيمياء المو اد النانوية المتقدمة و الحفز ـ قسم الكيمياء الفيزيقيةـ المركز القومى للبحوثــ الدقى ـ الجيزة-

تم تحضير الفريتات المختلطة المحتوية على كميات معينة من كاتيونات الماغنسيوم و المنجنيز باستخدام

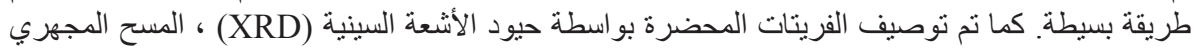
الإلكتروني (SEM) و التحول الطيفي بالأشعة تحت الحمر اء (FTIR) وتقنية الأشعة السينية المشتتة للطاقة

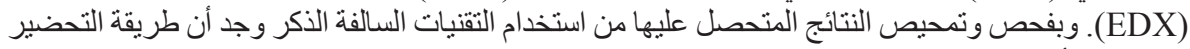

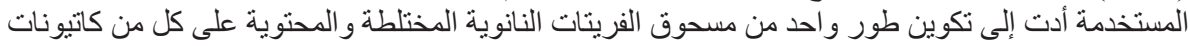

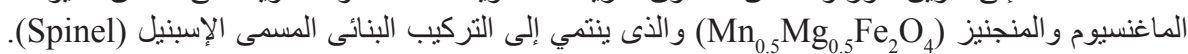

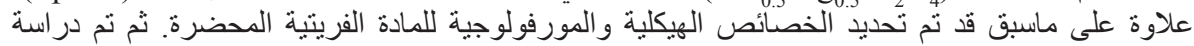

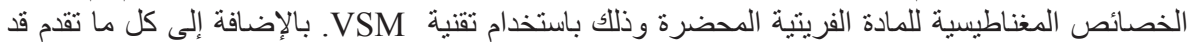

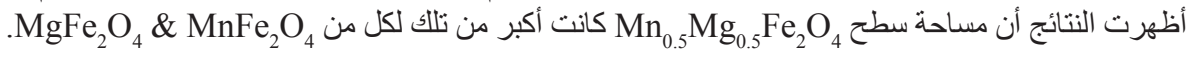

